\title{
MERCURY BIOACCUMULATION OF MACROBENTHOS BASED ON FEEDING BEHAVIOR AND NICHESAT LAMPON CEASED TRADITIONAL GOLD MINING, BANYUWANGI DISTRICT, EAST JAVA
}

\author{
Susintowati ${ }^{1}$ and Suwarno Hadisusanto ${ }^{2}$ \\ FKIP Universitas 17 Agustus 1945 Banyuwangi \\ 2 Laboratorium Ekologi Fakultas Biologi Universitas Gadjah Mada Yogyakarta \\ Email: susintowati@yahoo.com
}

\begin{abstract}
The bioaccumulation of mercury in the areas of Lampon traditional gold mining still be traced, although the mining activity was stopped. This research traces mercury bioaccumulation in macrobenthos at Lampon areas. The bioindicators were used the representatives macrobenthos based on the trophic levels, feeding behavior and niches. Mercury were analized by SNI 06-6992.2-2004 with modified at LPPT UGM Yogyakarta. The results shows different accumulation of mercury in specimens based on feeding behavior and niches. Nonsessile benthos accumulate higher than the sessile. Benthic filter feeders in free colony will accumulate mercury higher than benthic filter feeders in massive sessile colony. Filter feeders in massive sessile colony was detected lower than solitary herbivores. If the benthic herbivores attached hardly at the rocks, they could detected in high consentration because their niche and behavior to go in the water rarely. Niches affect ability of macrobenthos to accumulate mercury, although in the same tropic levels and feeding behavior.
\end{abstract}

Key words: mercury bioaccumulation, macrobenthos, trophic level, feeding behavior, niches

\section{INTRODUCTION}

Lampon was one of traditional gold mine that used amalgamation process at Banyuwangi District. While it was ceased at the middle of 2011 , it still be impacting around this region. The waste, that was disposal from tailing process would be cause mercury pollution to the environment. The waste accumulation cannot reduce in short time, but it will be far disperse if it carried with the spring water to up the estuary. Even gold mining process had been stopped, its effect in mercury pollution still can be traced. This research traces mercury bioaccumulation in macrobenthos at Lampon rocky shore.

Methylmercury (Me-Hg) is highly toxic particularly to the nervous system, and the developing brain is thought to be the most sensitive target organ for methylmercury toxicity. Mercury can be accumulate in the body of organisms, because it is in other water-soluble chemicals that bind tightly to specific siteswithin the body, these may accumulate. Bioaccumulation refers to how pollutants enter a food chain. Biomagnification refers to the tendency of pollutants to concentrate as they move from one organism to the next. Bioaccumulation increase in concentration of a pollutant from theenvironment to the first organism in a food chain. Biomagnification increase in concentration of a pollutant from one link in afood chain to another. Bioindicators are the organisms that used to detect how some pollutans accumulate in they bodies. Macrobenthos can be used as a bioindicator to traces of mercury (Eisler, 1987; Palar, 2008; Widowati, 2008; Neustadt \& Pieczenik, 2011).

The analysis results on mercury dispersion modelling of meteorological parameters showed that wet mercury deposition is dependent on recipitation, but dry mercury deposition is influenced by various meteorological factors (Lee \& Keener, 2008). Bowles et al. 
(2001) given a suggest that mercury accumulation in the body of fish related with an age. The results of observation by Baeyens et al. (2003) shows for each of the Belgian coastal zone fourspecies, a weak positive correlation between mercury content andfish length was found; however, the larger the size-range, thebetter the correlation. Taking fish length into account, astatistically significant difference in contamination level wasobserved for species sampled from the different geographicalzones.

The mercury bioaccumulation in aquatic biota significantly correlates with the mercury concentrations in the environmental media. Yoga et al. (2009) suggest that theperiphyton had the highest mercury bioaccumulation, subsequently followed by the scraper,the collector filterer, the collector gatherer, the shredder and finally the predator. Some authors suggest that a trophic shift occured in response to sediment contaminants, but they were unable to dismiss other factors (such as hypoxia) that may have played a role in benthic trophic structure. No significant relationship between benthic trophic structure and totalorganic carbon of superficial sediments, and none would be expected unless food were limiting (Gaston et al., 1998).

When biomass was considered, filter feeders and filter feeders/detritivores were the dominant groups in the estuary, while for the adjacent coastal shelf filter feeders represented $83 \%$ of the total biomass. Salinity, depth and sediment composition were the main factors structuring spatial distribution. Surface-deposit feeders were the most abundant macrobenthos of the upper estuary. Surface deposit feeders alsodominated the middle and the lower estuary but the proportion of filter feeders as well as other trophic groups increased with salinity (Gaudéncio \& Cabral, 2007).

The Bivalve (macrobenthos) species had contrasting feeding niches, which may also affect the $\mathrm{Hg}$ accumulation. Methylmercury is produced by methylation of inorganic mercury present in both freshwater and saltwater sediments, and accumulates in aquatic food chains in which the top-level predators usually contain the highest concentrations (Clarkson \& Marsh, 1982 in: Eisler, 1987). Methylmercury concentrations increased with trophic level (Bowles et al., 2001). This research traces mercury bioaccumulation at Lampon based on different trophic levels, feeding behavior and niches of macrobenthos.

\section{MATERIAL AND METHODS}

Lampon estuaries was administratively located in Banyuwangi, East Java. This research taken placed from August 2011 to May 2012, and had cover data from dry season to rainy season during that time. Method that used in this research to collect samples was random sampling.The bioindicators were used the representatives macrobenthos based on the trophic levels, feeding behavior and niches. Macrobenthos were assigment to a trophic level (groups) based on feeding behavior and food type preferences documented in the literature. Macrobenthic taxa were assigned to trophic level based on feeding morphology (in situ) too. The macrobenthos was taken from some niches that every niche with 2 or 3 different species, to each spesies were taken 2-5 specimens for preparation to mercury analysis. To identified species of the specimen were used the data and sample picture in literatures at laboratory. The specimens were fixation with $4 \%$ formaldehyde before preparation to mercury analysis. Mercury concentration were analyse based on SNI method 06-6992.2-2004 
(with modification) and Mercury Analyser at LPPT UGM, Yogyakarta.

Environmental parameters recorded (in situ) in this research were: current speed, water flow of estuary, tidal range (maximum tidal rise and drop / receding water maximum), salinity, dissolved oxygen in water and air (DO), water temperature and air temperature, precipitation, and the degree of the water acidity $(\mathrm{pH})$. The overall analysis of the data of the results based on mercury accumulation in the body of specimens and qualitative descriptive analysis.

\section{RESULTS AND DISCUSSION}

The external factors such as the datas of environment parameter shows that the condition of this areas still under normally value (Table 1 ). The normal value of environmental factors for marine organisms: $28-32^{\circ} \mathrm{C}$ of temperature, $7-8.5$ of acidity, dissolved oxygen $>5$ $\mathrm{mg} / \mathrm{l}$, water salinity until $34 \%$ (Kep.MenLH 51 of 2004). About of the environmental study, Schiener \& Willig (2008) present the sevent fundamental principles, included: (1) Organisms are distributed in space and time in a heterogeneousmanner. (inclusionary rule), (2) Organisms interact with their abiotic and biotic environments.(inclusionary rule), (3) The distributions of organisms and their interactions depend oncontingencies. (exclusionary rule), (4) Environmental conditions are heterogeneous in space and time. (causal rule), (5) Resources are finite and heterogeneous in space and time. (causal rule), (6) All organisms are mortal. (causal rule), (7) The ecological properties of species are the result of evolution.(causal rule). But, according to Sivadas et al. (2013), the indicates that the temporal environmental variation influenced the macrofaunalfunctional diversity pattern.

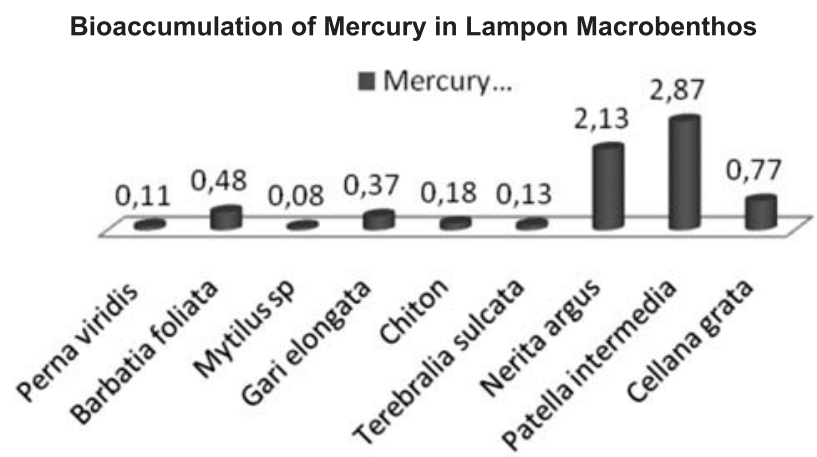

Figure 1. Bioaccumulation of mercury in Lampon Macrobenthos atter the amalgamation proccess and the tailing wasting have been enclosed.

Table 1. The values of Environment Factors at Lampon

\begin{tabular}{lll}
\hline Environment Parameters & Value & Unit \\
\hline Air Dissolved Oxygen & $6.26 \pm 0.26$ & $\mathrm{mg} / \mathrm{l}$ \\
Water Dissolved Oxygen & $7.16 \pm 0.04$ & $\mathrm{mg} / \mathrm{l}$ \\
Air Temperature & $32.24 \pm 0.17$ & ${ }^{0} \mathrm{C}$ \\
Water Temperature & $29.76 \pm 0.15$ & ${ }^{0} \mathrm{C}$ \\
Sediment Temperature & $31.60 \pm 0.28$ & ${ }^{0} \mathrm{C}$ \\
Water Salinity & $29.8 \pm 0.16$ & $\%$ \\
Water Acidity & $8.62 \pm 0.03$ & \\
Sediment Acidity & $6.40 \pm 0.28$ & \\
Water curret & 0.27 & $\mathrm{~m} / \mathrm{sec}$ \\
Water flow & 3.23 & $\mathrm{~m} / \mathrm{sec}$ \\
Tidal range & 1.29 & $\mathrm{~m}$ \\
\hline
\end{tabular}

Note: the datas was taken during October 2011 at low tide 12.00-14.00 The West Indonesia Time 
Mercury in natural aquatic environments with a range of $0.15 \mu \mathrm{g} / \mathrm{lin}$ sea water while the river water $0.07 \mathrm{mg} / \mathrm{l}$. The standard recomendation in Indonesia is $0.001 \mathrm{mg} / \mathrm{l}$ (Kep.MenLH 51 of 2004). According to Susintowati (2012), the dispersion of the existing tailings residual mercury from the gold amalgamation is the most influential tought of abiotic factors. While the other environmental factors are still in normal range. According to Gaston et al. (1998) and Ysebaert et al. (2003) the benthic macrofauna correlated very well with environmental factors (depth, salinity, tidal current velocity, sedimen composition). The correlation is strongly associated with a residential macrobenthos niches. This research took the main niches on the rocky shore and estaurine also mangrove. But for each site of niches we were got the speciments as sample only that representative in lifestyle and feeding behavior.

Table 2. The lifestyle and the characters of feeding behavior and niche of macrobenthos at Lampon

\begin{tabular}{lllll}
\hline Species & Function & Lifestyle & $\begin{array}{l}\text { Feeding } \\
\text { Behavior }\end{array}$ & Niche \\
\hline Perna viridis & edible & sessile in not massive colony & filter feeder & epifauna \\
Barbatia foliata & edible & sessile in not massive colony & filter feeder & epifauna \\
Mytilus $s p$ & edible & sessile in massive colony & filter feeder & epifauna \\
Gari elongata & edible & infauna/free colony & filter feeder & infauna \\
Chiton & edible & epifauna/solitair addesive at the holesof rocks & herbivore & epifauna \\
Terebralia sulcata & edible & epifauna/solitair & detrivor & epifauna \\
Nerita argus & unknown & epifauna/free colony & detrivor & epifauna \\
Patella intermedia & edible & epifauna/solitair addesive at the rocks & herbivore & epifauna \\
Cellana grata & edible & epifauna/solitair addesive at the rocks & herbivore & epifauna \\
\hline
\end{tabular}

Note: The characters of lifestyle actually based on observation at this place, the function based on interview with the most people that fishing the kind of species during the research sampling.

Perna viridis, Barbatia foliata, Mytilus sp, and Gari elongata is Bivalvia.In this site (Lampon) the speciments of Perna viridis were found attached to rocks with a maximum number of 3-5 individuals, mostly just stick alone. In this situation Pernaviridis is a vive that is settled, but not in massive colonies. Barbatia foliata almost the same as Perna viridis, but Barbatia foliata have the same inhenrent characters with Perna viridis. Perna viridis is one type of shellfish that have high economic value with densities of up to 35,000 individu/ $\mathrm{m}^{2}$ (Urian, 2009). The colony of Mytilus sp is a very solid and tight. Gari elongata is a not sessile Bivalvia, they are burrowing in the mud or sediment in the middle of water flow of the estuary. In this area, Gari elongata can be found in $5-10 \mathrm{~cm}$ in depth of sediment. So that, Gari elongata is infauna that they are as a subsurface filter feeder.

The character of niches and eating behavior of macrobenthos at Lampon indicated in correlated with the ability to accumulate of mercury. According to Susintowati (2012) the levels of mercury in Lampon estuarine sediments up to $65.52 \mathrm{ppm}$ and the remaining tailings up to $634.52 \mathrm{ppm}$. This result can be indicated that the mercury still be dispersion persisted to this research data is obtained, because the residence time of mercury in aquatic sediments and watershed can not be immediately eliminated (Eisler, 1987). This is evidenced by the results of the analysis of mercury in the body makrobentos Lampon.

Perna viridis, Barbatia foliata and Mytilus sp in the same of feeding behavior and trophic level, they are a surface filter feeder and deposit feeder but ability to accumulate mercury looks different. The colony characters suspected to be the cause of differences in the accumulation of mercury. Perna viridis average mercury accumulates up to $0.11 \mathrm{ppm}$ (the highest 
accumulation of $0.18 \mathrm{ppm}$ ), Barbatia foliata $0.48 \mathrm{ppm}$ (the highest accumulation of 0.83 $\mathrm{ppm}$ ), Mytilus sp $0.07 \mathrm{ppm}$ (the highest accumulation of $0.08 \mathrm{ppm}$ ). Barbatia foliata who have the same inherent character with Perna viridis can accumulate higher mercury. Mytilus $\mathrm{sp}$ has a very massive colonies. Accumulation of mercury are likely to be lower because of the competition allegedly to obtain food in the colony. Enter and accumulate mercury in their bodies suspected food along with the screening process, so the competition is high will also affect the accumulation of mercury. Gari elongata accumulates an average $0.38 \mathrm{ppm}$ and the highest accumulation of up to $0.56 \mathrm{ppm}$. The lifestyle of Gari elongata as infauna that bury themselves in the mud sediment can accumulate mercury high enough. Although colony Gari elongata is not attached, the location where the data Gari elongata population is quite high. Competition in taking food from the environment also affect the accumulation of mercury in the body, due to the inclusion of mercury in their bodies suspected strongly associated with feeding behavior. Eisler (1987) states that, the ability to accumulate pollutants are also influenced by genetic characters. So if the accumulation of mercury in the body of each specimen is different, there are allegations influenced by genetic factors.

The ability of mercury accumulation in makrobentos as herbivores that are also observed in this study. Chiton (Amphineura) are herbivores that are attached to the rock, but the animals tend niches in areas affected by water splashes. Pattela intermedia and Cellanagrata (Patteloids) are Gastropods with niche character similar to Chiton. However, Pattelaintermedia and Cellana grata was heading into a puddle if it's low tide, although rarely arrives. Most of them will soon be firmly attached to the rock and will not move up to replace the flooded rock. At high tide, they also tend to leave the waves and water waves heading into areas that are not flooded by water after they do the grazing algae.

The results of mercury accumulation shows Chiton can accumulate up to $0.18 \mathrm{ppm}$. Patella intermedia can accumulate an average of $0.29 \mathrm{ppm}$ and the highest accumulation of up to $0.44 \mathrm{ppm}$. Cellana grata can accumulate up to $0.77 \mathrm{ppm}$. Based on the value of the accumulated of mercury, Cellana grata is the higher than Chiton and Pattela intermedia. Cellana grata niches coincide with Chiton and Pattela intermedia. All three species are non-sessile (motile) and solitary. Allegations of competition in making food is also a factor that determines the amount of mercury accumulation in the body of these animals.

When compared with the filter feeder (Bivalvia), herbivorous benthos (Gastropoda) that are non-sessile shown to accumulate higher mercury. Ability to move freely while grazing, and their habits are very tightly shut down during low tides arrive suspected to be the cause of high mercury accumulation. Heath (1987) and Neustadt \& Pieczenik (2011) states that mercury accumulates in the body of an organism can be eliminated through excretion and detoxification process by hepatopancreas. While connected with this statement, supposedly minimize excretion character with firmly attached to the rock caused the accumulation of mercury in the body Patella intermedia and Cellana grata high enough.

Nerita argus and Terebralia sulcata is also a bioindicator (Gastropods) in this study. They are epifauna. Nerita argus is located in the rocky shore as a detrivor. While Terebralia sulcata is detrivor on the mangrove floor. They are in the same of trophic levels but in different niches. They are showing the ability of mercury accumulated nearly the same. Nerita argus average of $2.13 \mathrm{ppm}$ and accumulate the highest mercury up to $3.03 \mathrm{ppm}$. Terebralia 
sulcata average mercury accumulates up to $1.30 \mathrm{ppm}$ and $3.10 \mathrm{ppm}$ highs. Deposition of mercury in the sediments on mercury-contaminated areas is higher than mercury dissolved in water (Heath, 1987). The feeding behavior that looking down of detritus for the food on sediments causing Nerita argus and Terebralia sulcata accumulate mercury in high value. Both have very high mercury accumulation ability than other bioindicators that have been mentioned previously.

Overall, it can be concluded that the ability of mercury bioaccumulation based on several specimens trophic levels, feeding behavior and niche. Benthic filter feeders and sessile but not in massive colonies will accumulate mercury more dense than massive. Non-sessile benthos accumulate higher than the sessile. Filter feeder with a massive colonies was lower than solitary herbivores. Niches affect the ability to accumulate mercury, although in the same of trophic levels or even the same of feeding behavior.

\section{REFERENCES}

Baeyens, M., M. Leermakers, T. Papina, A. Saprykin, N. Brion, J. Noyen, M. De Gieter, M. Elskens, and L. Goeyens. 2003. Bioconcentration and Biomagnification of Mercury and Methylmercury in North Sea and Scheldt Estuary Fish. Arch. Environ. Contam. Toxicol. 45, 498-508.

Bowles, K.C., S.C. Apte, W.A. Maher, M. Kawei, and R. Smith. 2001. Bioaccumulation and biomagnification of mercury in Lake Murray, Papua New Guinea. Can. J. Fish. Aquat. Sci. 58: 888-897.

Eisler, R. 1987. Mercury Hazards to Fish, Wildlife and Invertebrates. A Synoptic Review. Biologycal Report: 85 (1:10).

Gaston, G.R., C.F. Rakocinski, S.S. Brown, and C.M. Cleveland. 1998. Trophic Function in Estuaries: Response of Macrobenthos to Natural and Contaminant Gradient. Mar.Freshwater.Res: 49.833-46.

Gaudéncio, M.J., and H.N. Cabral. 2007. Trophic Structure of Macrobenthos in the Tagus Estuary and Adjacent Coastal Shelf. Hydrobiologia. 587:241-251.

Heath, A.G. 1987. Water Pollution and Fish Physiology. CRC Press Inc. Boca Raton. Florida. Lee, S-S., and T.C. Keener. 2008. Dispersion Modeling of Mercury Emissionsfrom CoalFired Power Plants at Coshoctonand Manchester, Ohio. The Ohio Journal ofScience, v108, n4 (September, 2008), 65-69.

Neustadt, J., and S. Pieczenick. 2011. Heavy-metal Toxiciy-With Emphasis on Mercury. Integrative Medicine. Vol.10,No.5:45-50.

Palar, H. 2008. Pencemaran dan toksikologi logam berat. Rineka Cipta Pub. Jakarta.

Scheiner, S.M., and M.R. Willig. 2008. A General Theory of Ecology. Theor.Ecol. 1:21-28. DOI 10.1007/s12080-007-0002-0.

Sivadas, S.K., B.S. Ingole, and C.E.G. Fernandes. 2013. Environmental Gradient Favours Functionally DiverseMacrobenthic Community in a Placer Rich Tropical Bay. The Scientific World Journal. Volume 2013, Article ID 750580: 1-12. Hindawi Publishing Corporation.

Susintowati. 2012. Mercury Bioaccumulation and Community Structure of Gastropod at Ceased Traditional Gold Mining Lampon Estuary, Banyuwangi District, East 
Java.Thesis Text. Unpublished. Gadjah Mada University. Yogyakarta.

Urian, A.G. 2009. Potential for range expansion of the invasive green mussel, Perna viridis, the Southeastern of North Florida. Thesis Text. Unpublished. University of North Florida.

Widowati, W., A. Sastiono, and R.R. Jusuf. 2008. Efek toksik logam. Pencegahan dan penanggulangan pencemaran. Andi's Pub. Yogyakarta.

Yoga, G.P., Y. Sudarso, T. Suryono, Awalina, M.H. Syawal, Yustiawati. 2009. Bioakumulasi Logam Merkuri Pada Beberapa Tipe Kebiasaan Makan Fungsional Biota Air Di Sungai Cikaniki. Limnotek. Vol. XVI. No. 2: 167-179.

Ysebaert, T., P.M.J. Herman, P. Meire, J. Craeymeersch, H. Verbeek, C.H.R. Heip. 2003. Large-scale spatial patterns in estuaries: estuarine macrobenthic communities in the Schelde estuary, NW Europe. Estuarine, Coastal and Shelf Science. 57: 335-355. 